\title{
Three Colopterus Beetle Species Carry the Oak Wilt Fungus to Fresh Wounds on Red Oak in Missouri
}

\author{
Maya Hayslett, Department of Plant Pathology, University of Wisconsin, Madison 53206; Jennifer Juzwik, United \\ States Department of Agriculture-Forest Service, Northern Research Station, St. Paul, MN 55108; and Bruce Moltzan, \\ Missouri Department of Conservation, Columbia 65201
}

\begin{abstract}
Hayslett, M., Juzwik, J., and Moltzan, B. 2008. Three Colopterus beetle species carry the oak wilt fungus to fresh wounds on red oak in Missouri. Plant Dis. 92:270-275.

Beetles in the family Nitidulidae can transmit the oak wilt fungus, Ceratocystis fagacearum, to fresh wounds on healthy oak trees, leading to infection and disease development. Historically, nitidulid beetles have not been considered important vectors of the pathogen in Missouri. Studies were conducted in the spring of 2005 and 2006 to determine frequencies of nitidulid beetle species contaminated with $C$. fagacearum visiting fresh wounds on red oak trees in central Missouri. Colopterus truncatus, $C$. niger, and $C$. semitectus were the most abundant species collected from fresh wounds and the only species found to be contaminated with Ceratocystis fagacearum. Of 230 beetles assayed for $C$. fagacearum, 23 yielded the fungus. Contamination frequencies were higher for beetles collected in April than May; no beetles collected in June were contaminated. We hypothesize that Colopterus truncatus, $C$. niger, and $C$. semitectus are principal nitidulid beetle vector species in Missouri during spring. The risk for pathogen transmission by these beetles appears to be greatest in April and least in June.
\end{abstract}

Additional keywords: insect vectors, Quercus spp.

Oak wilt, caused by the fungus Ceratocystis fagacearum, is a serious disease of oak (Quercus spp.) in the eastern United States and Texas. Infection in red oak (Quercus sp. section Lobatae) can lead to tree death in as little as 3 weeks (11). White oak (Quercus sp. section Quercus) are susceptible to the disease; however, disease development is slower and does not always lead to death. Oak wilt occurs in 84 of 114 Missouri counties based on a recent United States Department of Agriculture Forest Service disease distribution map (J. O'Brien, personal communication). Oak is an important timber species group in Missouri, with red oak accounting for $48 \%$ of total industrial roundwood volume and half of saw log volume in 2000 (25). Oak species also are common in Missouri's urban forests (29).

Overland spread of the oak wilt fungus occurs when nitidulid beetles (Coleoptera: Nitidulidae) visit fresh wounds on oak trees following acquisition of fungal propagules from fungal mats on oak-wiltkilled trees (11). In most geographic areas,

Corresponding author: M. Hayslett

E-mail: mch@plantpath.wisc.edu

Accepted for publication 21 September 2007.

doi:10.1094/PDIS-92-2-0270

This article is in the public domain and not copyrightable. It may be freely reprinted with customary crediting of the source. The American Phytopathological Society, 2008. this type of spread is more common in spring. Although the fungus also may spread via root grafts to adjacent trees, Missouri oak species are diverse and interspecific root connections are not common (14). Also, Missouri oak trees typically grow on clay pan (coarse-textured) soils which further limit root graft establishment. Therefore, current theory is that, in Missouri, insect vectors are largely responsible for spreading the oak wilt fungus within and to adjoining stands (B. Moltzan, unpublished).

Initial surveys conducted in Missouri suggested that overland transmission of the oak wilt fungus by nitidulid beetles was not important due to the lack of fungal mat formation (4). Researchers concluded that oak bark beetles (Coleoptera: Scolytidae) were responsible for overland transmission in the state $(4,5,26)$. More recently, fungal mats have been observed on various red oak species and confirmed as part of the Forest Inventory Analysis Program in Missouri (20,21; J. Juzwik and B. Moltzan, unpublished). More information is now needed on nitidulid beetle transmission of oak wilt in Missouri.

Whereas the whole family of nitidulid beetles has been implicated in transmission of the oak wilt fungus (10), research done in Minnesota $(7,17)$ and Iowa (22) provides evidence that certain species in this family are more closely associated with the fungus and are likely the principal vector species. Control of overland spread of oak wilt relies on prevention of wounding oak trees or covering wounds that are made during periods of high risk to infection and removal of potential mat-producing trees $(15,23)$. Different species of nitidulid beetles have different flight times and generation cycles. Therefore, when the specific species responsible are known, high-risk periods can be more readily and accurately determined.

In Minnesota, Colopterus truncatus and Carpophilus sayi have been distinguished as important oak wilt vectors and are known to disperse with Ceratocystis fagacearum on their bodies in April, May, and June $(2,17)$. It remains unknown if the same species are responsible in Missouri or if the same time frame applies. Differences in the seasonal climate, landscape, and oak species composition may create a different vector situation, and control methods may need to be modified.

To identify those species involved in pathogen transmission, knowledge about what species are carrying the fungus to fresh wounds is needed. Presumably, those nitidulid beetle species found in large numbers in wounds and contaminated with the fungus are the species most likely involved in the transmission of the oak wilt fungus (17). Wounding studies were conducted in the spring of 2005 and 2006 in central Missouri to (i) evaluate the relative abundance of nitidulid beetle species visiting fresh wounds on healthy red oak in oak wilt centers, (ii) determine which species are contaminated with $C$. fagacearum, and (iii) gather data on the timing of contaminated beetle presence.

\section{MATERIALS AND METHODS}

Study sites. Sites were selected in central Missouri that consisted of active oak wilt centers with nearby healthy red oak trees. Active oak wilt centers were defined as those with red oak trees killed by $C$. fagacearum the previous year. Fungal mats were expected to form on some of these trees and, thus, serve as inoculum sources during the spring. A brief survey to look for mat production was conducted at each site in April only of both study years. The nearby healthy red oak trees were wounded to serve as attractants and infection courts.

Four oak-wilt-killed red oak trees were found at Perry Conservation Area (CA) located in west-central Missouri in 2005, with one tree forming fungal mats in early 
April. One oak-wilt-killed red oak with declining mats was present at Little Lost Creek CA located in east-central Missouri in 2005. In 2006, a third site, Prairie Garden Trust, located in central Missouri, was added because no additional healthy red oak trees were available at Perry CA. Four oak-wilt-killed red oak trees were present at Prairie Garden Trust but no mat formation was observed. Three oak-wilt-killed trees were present at Little Lost Creek CA in 2006, with two forming fungal mats.

Wounding of healthy trees. Each year, 10 to 12 trees were wounded at each site. Wounds were made once a month in midApril, mid-May, and mid-June each year. Each tree was wounded twice, once on the east-facing side and once on the westfacing side, during each wounding event. Wounds were made approximately $1.5 \mathrm{~m}$ off the ground on the main stem. A portable electric drill with hole-saw drill bit was used to remove a 5-cm-diameter round bark plug with a hole in the center to the outer xylem ring. Each removed bark plug was reinserted and held in place with a galvanized nail to create a niche for the nitidulid beetles. Rain flaps, made of file folders sprayed with silicon to enhance water resistance, were attached above the wound using a staple gun and then sealed with caulk to prevent rain from washing beetles out of the wounds.

Beetle collection. Beetles were collected from wounds once each day for 6 to 9 days following each wounding event. In 2005 , beetles were collected for 6 days following each wounding event, except for at Little Lost Creek CA in May, when beetles were collected for 5 days after wounding and also on the ninth day after wounding. In 2006, beetles were collected for 7 days following each wounding event. A collection container sterilized with $70 \%$ ethanol was placed under the wound to collect falling insects as the bark plug was removed. Beetles were picked up quickly with forceps sterilized with $70 \%$ ethanol and placed on a piece of filter paper on a plastic disposable petri dish. The dish then was placed on ice to slow the movement of the beetles. Subsequently, beetles were placed individually in sterilized $1.5-\mathrm{ml}$ microcentrifuge tubes labeled with the date, site, and tree number. Beetles in microcentrifuge tubes were stored on ice in the field and transferred to cold storage in a freezer until shipped on ice to the laboratory in St. Paul, MN for processing. Beetles were stored in a freezer until identified and assayed for the fungus.

All beetles were identified to species and the number of each species recorded. Beetles were identified using descriptions provided by Parsons (24) as well as by comparison with previously identified specimens. Identifications were verified by Michelle Price (Department of Entomology, University of Wisconsin, Madison) using provided specimens of each species. Voucher specimens were deposited in the Insect Museum, Department of Entomology, University of Minnesota, St. Paul by Maya Hayslett.

Beetle processing. Beetles were processed to isolate $C$. fagacearum from the beetle's surface and interior. Beetles in their individual microcentrifuge tubes were macerated in $0.5 \mathrm{ml}$ of sterile water with a tip sonicator to dislodge and expose fungal material. This aqueous suspension of macerated beetle was used to create three 10fold dilutions with $0.5 \mathrm{ml}$ of each plated on each of three lactic-acid-amended (acidified) potato dextrose agar plates. These plates were incubated in the dark at $24^{\circ} \mathrm{C}$ and examined after 10 days for presence or absence of the fungus (7). Colonies of $C$. fagacearum were identified by morphology and presence of endoconidia (3). The numbers of colonies on each plate for the dilution series yielding 20 to 50 colonies per plate were counted and the CFU per beetle were calculated.

Data analysis. Counts of beetles were standardized by the number of days collections were made and the number of trees wounded in order to obtain mean counts.
For plotting time series data, a natural log transformation was made using the formula $\operatorname{Ln}(X+1)$ to account for data with zeros. Total beetle numbers were used for statistical analyses.

Due to the low numbers of beetles collected at Perry CA in 2005 and Prairie Garden Trust in 2006, statistical analyses were done with Little Lost Creek CA data only. Poisson regression, in the software program ARC (8), was used to analyze the number of beetles collected in wounds. The number of beetles collected of the species identified as abundant was the response variable while the predictor variables were year, month, days after wounding, and species. Interactions were not analyzed due to the limited data available.

Binomial regression in ARC was used to analyze the presence or absence of pathogen propagules on or in the beetles of three predominant species. Each beetle was scored as a 1 if $C$. fagacearum was isolated and a 0 if not. Few beetles were contaminated with the fungus. Differences between years and months were large; therefore, comparison of these variables was done without statistical analysis. Statistical analysis was done with months and years combined using only the species and days after wounding as predictor variables.

\section{RESULTS}

Beetle species abundance. Fourteen species of nitidulid beetles were collected over the 2 years (Table 1). About 10 times more beetles were collected at Little Lost Creek CA in 2005 and 2006 compared with Perry CA in 2005 and Prairie Garden Trust in 2006 (Table 1). Colopterus truncatus, $C$. semitectus, and $C$. niger represented $65 \%$ of all beetles captured at Little Lost Creek CA during both years (Table 1). Cryptarcha ampla was the fourth most abundant species overall but still less than half as abundant as the third most abundant species (Table 1). Due to the lack of beetle captures at Perry CA and Prairie Garden Trust, all subsequent data analysis of bee-

Table 1. Nitidulid beetle captures and catch rates from fresh wounds on red oak trees in spring in Missouri ${ }^{\mathrm{a}}$

\begin{tabular}{|c|c|c|c|c|c|c|c|c|c|}
\hline \multirow[b]{2}{*}{ Beetle species } & \multicolumn{2}{|c|}{ Perry 2005} & \multicolumn{2}{|c|}{ Lost Creek 2005} & \multicolumn{2}{|c|}{ Prairie Garden 2006} & \multicolumn{2}{|c|}{ Lost Creek 2006} & \multirow{2}{*}{$\begin{array}{c}\text { All sites } \\
\begin{array}{c}\text { Catch } \\
\text { rate }\end{array}\end{array}$} \\
\hline & $\begin{array}{c}\text { No. of } \\
\text { beetles }\end{array}$ & $\begin{array}{c}\text { Catch } \\
\text { rate }\end{array}$ & $\begin{array}{c}\text { No. of } \\
\text { beetles }\end{array}$ & $\begin{array}{c}\text { Catch } \\
\text { rate }\end{array}$ & $\begin{array}{l}\text { No. of } \\
\text { beetles }\end{array}$ & $\begin{array}{c}\text { Catch } \\
\text { rate }\end{array}$ & $\begin{array}{c}\text { No. of } \\
\text { beetles }\end{array}$ & $\begin{array}{c}\text { Catch } \\
\text { rate }\end{array}$ & \\
\hline Colopterus truncatus & 0 & 0.00 & 4 & 1.85 & 4 & 1.59 & 66 & 26.19 & 29.63 \\
\hline C. semitectus & 0 & 0.00 & 11 & 5.09 & 5 & 1.98 & 48 & 19.05 & 26.12 \\
\hline C. niger & 0 & 0.00 & 17 & 7.87 & 3 & 1.19 & 24 & 9.52 & 18.58 \\
\hline C. maculatus & 1 & 0.53 & 9 & 4.17 & 1 & 0.40 & 1 & 0.40 & 5.49 \\
\hline Carpophilus sayi & 1 & 0.53 & 1 & 0.46 & 0 & 0.00 & 19 & 7.54 & 8.53 \\
\hline C. corticinus/C. antiquus & 0 & 0.00 & 1 & 0.46 & 1 & 0.40 & 8 & 3.17 & 4.03 \\
\hline Cryptarcha ampla & 5 & 2.63 & 14 & 6.48 & 0 & 0.00 & 0 & 0.00 & 9.11 \\
\hline C. concinna & 0 & 0.00 & 7 & 3.24 & 1 & 0.40 & 0 & 0.00 & 3.64 \\
\hline Lobiopa undulata & 0 & 0.00 & 14 & 6.48 & 2 & 0.79 & 1 & 0.40 & 7.67 \\
\hline Glischrochilus obtusus & 0 & 0.00 & 5 & 2.31 & 0 & 0.00 & 2 & 0.79 & 3.11 \\
\hline Amphicrosis ciliatus & 0 & 0.00 & 5 & 2.31 & 0 & 0.00 & 0 & 0.00 & 2.31 \\
\hline Prometopia sexmaculata & 0 & 0.00 & 3 & 1.39 & 0 & 0.00 & 1 & 0.40 & 1.79 \\
\hline Epurea sp. & 0 & 0.00 & 0 & 0.00 & 0 & 0.00 & 1 & 0.40 & 0.40 \\
\hline Total & 7 & 3.68 & 91 & 42.13 & 17 & 6.75 & 171 & 67.86 & $\ldots$ \\
\hline
\end{tabular}

a Catch rate $=$ mean beetles per tree per day $\times 100$. 

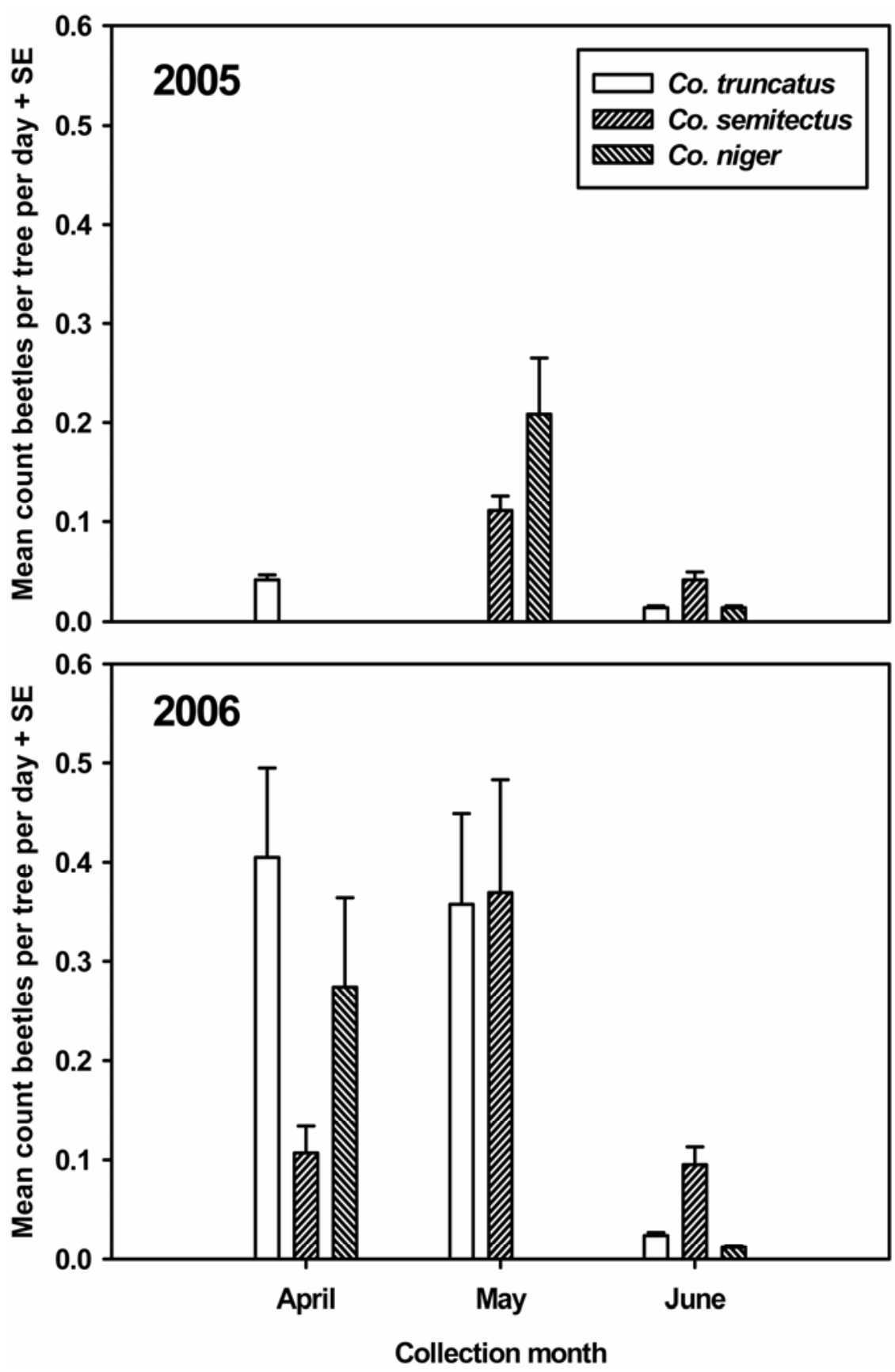

Fig. 1. Mean counts of three Colopterus spp. of beetles per tree per day per month collected from fresh wounds on red oak trees at Little Lost Creek Conservation Area in Missouri in spring.

Table 2. Poisson regression analysis of explanatory variables for number of Colopterus truncatus, C. niger, and $C$. semitectus beetles captured from fresh wounds over time ( 1 to 3 and 4 to 9 days after wounding) on 12 healthy red oak trees at Little Lost Creek Conservation Area in Missouri in April, May, and June in 2005 and 2006

\begin{tabular}{llcrrr}
\hline Variable & \multicolumn{1}{c}{ Level } & Estimate & SE & Wald $\chi^{2}$ & P value \\
\hline Constant & . & 0.3911 & 0.2523 & 2.4029 & 0.1211 \\
Year & 2006 vs. 2005 & 1.4615 & 0.1962 & 55.4879 & $<0.0001$ \\
Month & May vs. April & 0.2085 & 0.1620 & 1.6564 & 0.1981 \\
& June vs. April & -1.4615 & 0.2775 & 27.7437 & $<0.0001$ \\
Day & Days 4-9 vs. 1-3 & 0.9620 & 0.1715 & 31.4740 & $<0.0001$ \\
Species & C. niger vs. C. truncatus & -0.5349 & 0.1967 & 7.3987 & 0.0070 \\
& C. semitectus vs. C. truncatus & -0.1710 & 0.1767 & 0.9357 & 0.3330 \\
\hline
\end{tabular}

a Model: number of $C$. truncatus, $C$. niger, and $C$. semitectus captures $=$ constant + year + month + day + species. All explanatory variables are factors where estimates are compared with the first level; $\mathrm{SE}=$ standard error. tle captures involved the Little Lost Creek CA data only. In addition, data analysis of beetle species captures was limited to the three most abundant taxa.

There were greater numbers and mean counts of Colopterus truncatus, C. niger, and $C$. semitectus in 2006 compared with 2005 (Fig. 1; Table 2; $P<0.0001$ ). Similar numbers of $C$. truncatus, $C$. niger, and $C$. semitectus were captured in May compared with April $(P=0.198$; Table 2). Fewer beetles were captured in June compared with April $(P<0.0001$; Table 2$)$. Fewer numbers of $C$. niger were captured compared with $C$. truncatus $(P=0.009$; Table 2). Mean counts of $C$. niger were low in June of both years (Fig. 1). C. niger mean counts in April and May varied widely by year, with no captures in April and high mean counts in May 2005 but high mean counts in April and no captures in May in 2006 (Fig. 1). Overall, there was no significant difference between the number of $C$. semitectus and $C$. truncatus captured $(P=0.29$; Table 2$)$.

There were greater numbers and mean counts of $C$. truncatus, $C$. niger, and $C$. semitectus in the last 4 to 9 days after wounding as opposed to the first 1 to 3 days of collection from the wounds $(P<$ 0.0001; Table 2; Fig. 2). However, C. truncatus, $C$. niger, and $C$. semitectus still were captured in the first 3 days after wounding; however, fewer captures were made (Fig. 2).

Beetle species with Ceratocystis fagacearum. Of 230 individual beetles assayed, 23 yielded the oak wilt fungus (Table 3). Colopterus truncatus, C. niger, and C. semitectus were the only beetle species contaminated with the fungus (Table 3 ). Furthermore, only beetles captured in April and May yielded the pathogen (Table 4). A higher contamination frequency was found in 2006, with the majority of contaminated beetles captured in April (31\% of all April beetles assayed; Table 4). In April 2006, $58 \%$ of the $C$. niger beetles were contaminated (Table 4) whereas, in April 2005, no $C$. niger beetles were collected (Fig. 1). $C$. niger was more likely to be contaminated than $C$. truncatus and $C$. semitectus $(P=$ 0.02; Table 5); however, similar contamination frequencies were found for the other two species $(P=0.56$; Table 5$)$. There was no difference $(P=0.38)$ in contamination frequencies for beetles collected on days 4 to 9 compared with days 1 to 3 after wounding (Table 5). CFU isolated per contaminated beetle ranged from 27 to 1,443. Propagule numbers were highest in April 2006 and somewhat lower in April and May 2005 as well as in May 2006 (Table 4).

\section{DISCUSSION}

Nitidulid beetles were collected from fresh wounds in all sites and years, but the abundance in each site-year-month combination varied greatly. Very few beetles ( $n$ 
$=7$ and 17) were obtained from Perry CA and Prairie Garden Trust, respectively, whereas much higher numbers were obtained from Little Lost Creek CA in both years. The level of mat production occurring in an oak stand may account for some of this variation. We speculate that fungal mats may be important in the build-up of nitidulid beetle populations, particularly if a species has a close association with Ceratocystis fagacearum and the oak wilt disease cycle. For example, Colopterus truncatus is commonly collected from oak wilt mats and fresh wounds on oak trees $(7,17,22)$. The species commonly oviposits and rears broods in oak wilt mats. $C$. truncatus is also an important pollinator of Calycanthus occidentalis (12) and the flowers of the species serve as a food source for the beetle (28); otherwise, other common habits of the species either are not known or have not been reported. Thus, a low or high level of mat production within an oak stand could be a predictor of low or high beetle captures, respectively, in wounds. Further research is needed to test this hypothesis. Other site factors also may help explain the variation in capture rates by site. Additional wounding studies conducted in a larger number of sites would be required to explore this possibility.

The relative abundance and diversity of species in wounds varies by region. In this study, 14 species of nitidulid beetles were collected from all sites and both years. This species richness is similar to that reported for $\leq 2$-week-old wounds on oak trees between April and June in northern Iowa sites in the 1950s (22). Fewer nitidulid beetle species were associated with wounds in West Virginia ( $n=11 \mathrm{spp}$; 30 ), Minnesota ( $n=8 \mathrm{spp}$; 17$)$, and Wisconsin ( $n=7$ spp.; 19). The three most abundant Colopterus spp. (truncatus, niger, and semitectus) accounted for $65 \%$ of all nitidulid beetles obtained from Little Lost Creek CA. In contrast, Colopterus truncatus and Carpophilus sayi composed $>95 \%$ of all nitidulid beetles in Minnesota (17). A few individuals of Colopterus semitectus also were collected in Minnesota. In Texas, C. truncatus accounted for $100 \%$ of 183 nitidulid beetles collected from freshly wounded oak trees in late February (13). C. niger was not collected in oak wilt stands in Minnesota and Carpophilus sayi, the other important vector species in Minnesota, was rarely collected in Missouri.

Similar or higher numbers of the three most abundant Colopterus spp. were collected from 4- to 7- or 9-day-old wounds compared with 1- to 3-day-old wounds. In contrast, in a similar study in Minnesota, higher numbers of nitidulid beetle adults generally were found in 1- to 3-day-old wounds versus 4- to 6-day-old ones (17). Susceptibility of wounds to infection by Ceratocystis fagacearum does decrease with age. Previous studies found wounds up to 2 to 4 days old with the highest frequencies of resulting infections and low frequencies of infections occurring 4 to 8 days after wounding $(18,32)$. If wounds are less susceptible or not susceptible for the full 6 to 9 days, then overland transmission may occur less often than the numbers reported here would suggest. However, at Little Lost Creek CA, three new infections occurred the first year of the study; all were in trees that had been wounded in 2005 and that were not within root-grafting distance of trees known to be infected. At this site, no trees that we had not wounded were wilted. This suggests that nitidulid beetle transmission of the fungus occurred at this site as a result of the wounds we created.
Studies specifically on wound susceptibility in Missouri or differences among Missouri oak species have not been reported.

In all, $10 \%$ of the nitidulid beetles captured from the fresh wounds that were assayed for the pathogen yielded the fungus. Although this shows that fungus-laden nitidulid beetles were available to transmit C. fagacearum in spring in Missouri, contamination rates were much lower than those of beetles from wounds in spring in Minnesota (17) and in late February in Texas (13). In Missouri, contaminated beetles were found in greatest numbers in April, with some in May and none in June.

Current control measures for oak wilt in Missouri include avoidance of wounding

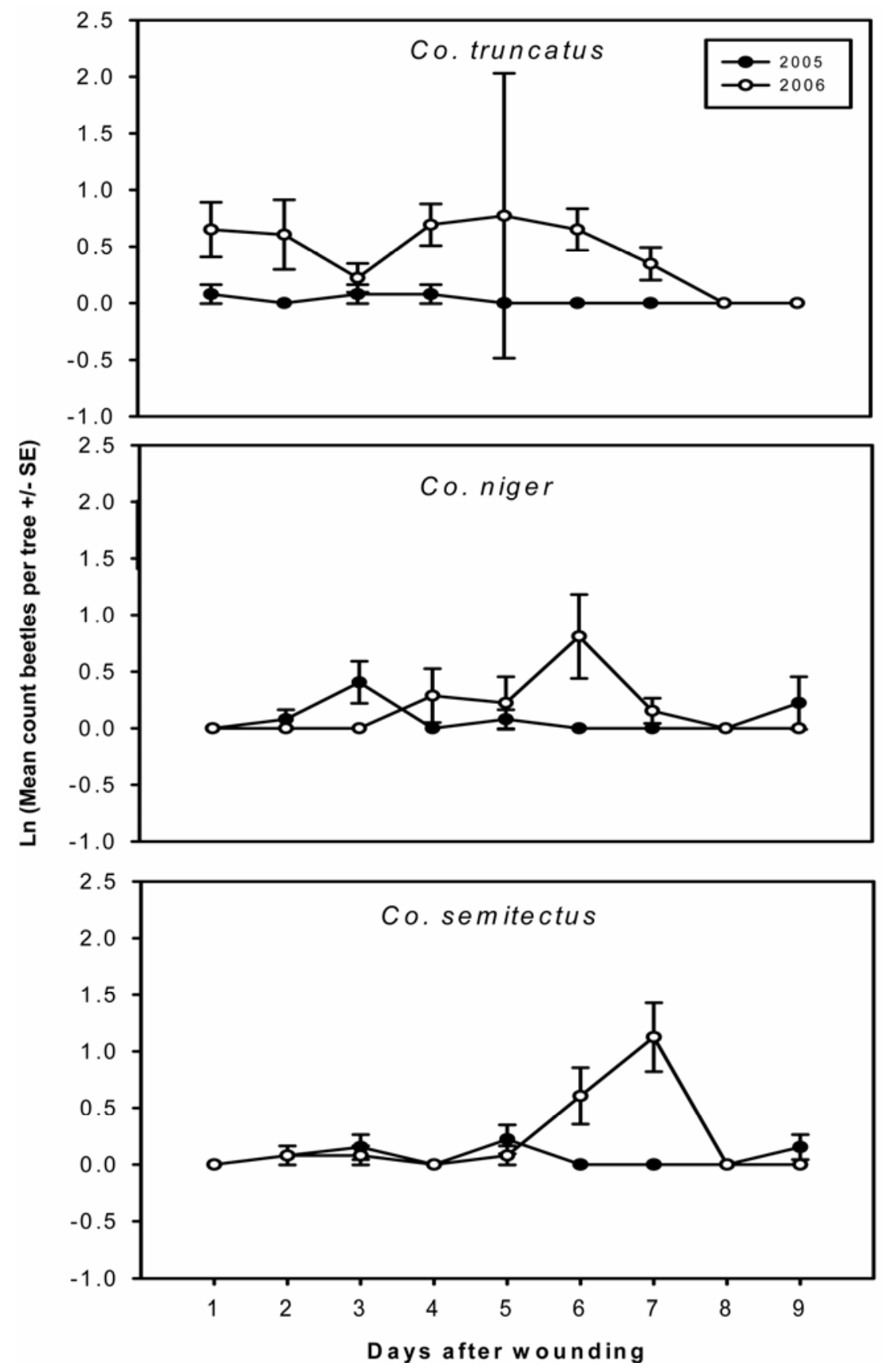

Fig. 2. Mean counts of three Colopterus spp. per tree per day after wounding collected from wounds on 12 red oak trees at Little Lost Creek Conservation Area in spring in Missouri. 
from April through June to prevent fungal infection. Our results suggest that April is a period of higher risk and that risk is lower in May and lowest in June. Additional data on the seasonal abundance of the three species identified as capable are needed to test this hypothesis. If oak trees could be wounded in June without risk of infection, this would give home owners, tree care professionals, and forest managers additional time to prune or harvest oak trees.

Because so little is known about mat production in Missouri, studies looking at the possibility of fall transmission by nitidulid beetles and the availability of inoculum should be done. Mats are known to form on oak-wilt-killed trees during late

Table 3. Isolation of Ceratocystis fagacearum (Cf) from nitidulid beetles collected from fresh wounds on 12 healthy red oak trees at Little Lost Creek Conservation Area in spring in Missouria ${ }^{\mathrm{a}}$

\begin{tabular}{|c|c|c|c|c|}
\hline \multirow[b]{3}{*}{ Nitidulid beetle species } & \multicolumn{4}{|c|}{ Number of beetles by year } \\
\hline & \multicolumn{2}{|c|}{2005} & \multicolumn{2}{|c|}{2006} \\
\hline & Assayed & With Cf & Assayed & With Cf \\
\hline Colopterus truncatus & 3 & 1 & 62 & 6 \\
\hline C. semitectus & 11 & 0 & 43 & 4 \\
\hline C. niger & 15 & 1 & 22 & 11 \\
\hline C. maculatus & 8 & 0 & 1 & 0 \\
\hline Cryptarcha ampla & 13 & 0 & 0 & 0 \\
\hline C. concinna & 6 & 0 & 0 & 0 \\
\hline Carpophilus sayi & 0 & 0 & 17 & 0 \\
\hline C. corticinus & 0 & 0 & 3 & 0 \\
\hline Lobiopa undulata & 13 & 0 & 1 & 0 \\
\hline Glischrochilus obtusus & 4 & 0 & 2 & 0 \\
\hline Amphicrossus ciliatus & 3 & 0 & 0 & 0 \\
\hline Prometopia sexmaculata & 2 & 0 & 1 & 0 \\
\hline
\end{tabular}

${ }^{a}$ With $\mathrm{Cf}=$ number of beetles contaminated with Ceratocystis fagacearum based on serial dilution plating assays.

Table 4. Frequency of Ceratocystis fagacearum isolated from three Colopterus spp. collected from fresh wounds on 12 healthy red oak trees at Little Lost Creek Conservation Area in Missouri

\begin{tabular}{|c|c|c|c|c|}
\hline \multirow[b]{2}{*}{ Collection ${ }^{\mathbf{a}}$} & \multirow[b]{2}{*}{ Colopterus spp. } & \multicolumn{2}{|c|}{ Number of beetles } & \multirow[b]{2}{*}{ Mean CFU/beetlec } \\
\hline & & Assayed & With Cf $\mathbf{f}^{\mathrm{b}}$ & \\
\hline \multicolumn{5}{|l|}{2005} \\
\hline \multirow[t]{3}{*}{ April } & Colopterus truncatus & 2 & 1 & 27 \\
\hline & C. semitectus & 0 & 0 & 0 \\
\hline & C. niger & 0 & 0 & 0 \\
\hline \multirow[t]{3}{*}{ May } & C. truncatus & 0 & 0 & 0 \\
\hline & C. semitectus & 8 & 0 & 0 \\
\hline & C. niger & 15 & 1 & 700 \\
\hline \multirow[t]{3}{*}{ June } & C. truncatus & 1 & 0 & 0 \\
\hline & C. semitectus & 3 & 0 & 0 \\
\hline & C. niger & 0 & 0 & 0 \\
\hline \multicolumn{5}{|l|}{2006} \\
\hline \multirow[t]{3}{*}{ April } & C. truncatus & 32 & 5 & $253 \pm 62$ \\
\hline & C. semitectus & 8 & 4 & $3,001 \pm 1,860$ \\
\hline & C. niger & 21 & 10 & $1,443 \pm 592$ \\
\hline \multirow[t]{3}{*}{ May } & C. truncatus & 28 & 1 & 3 \\
\hline & C. semitectus & 28 & 1 & 67 \\
\hline & C. niger & 0 & 0 & 0 \\
\hline \multirow[t]{3}{*}{ June } & C. truncatus & 2 & 0 & 0 \\
\hline & C. semitectus & 7 & 0 & 0 \\
\hline & C. niger & 1 & 0 & 0 \\
\hline
\end{tabular}

${ }^{a}$ Collection year and month.

${ }^{\mathrm{b}}$ Number of beetles contaminated with Ceratocystis fagacearum.

${ }^{c}$ Average number of CFU per contaminated beetle \pm standard error when appropriate.

Table 5. Binomial regression analysis of explanatory variables for presence of Ceratocystis fagacearum on Colopterus truncatus, C. niger, and C. semitectus captured from fresh wounds on 12 healthy red oak trees over time ( 1 to 3 and 4 to 9 days after wounding) during spring at Little Lost Creek Conservation Area in Missouri in 2005 and 2006 ${ }^{\mathrm{a}}$

\begin{tabular}{llrrrr}
\hline Variable & \multicolumn{1}{c}{ Level } & Estimate & SE & Wald $\chi^{\mathbf{2}}$ & $\boldsymbol{P}$ value \\
\hline Constant & $\ldots$ & -2.5926 & 0.5669 & 20.9147 & $<0.0001$ \\
Species & C. niger vs. C. truncatus & 1.2416 & 0.5328 & 5.4306 & 0.0198 \\
& C. semitectus vs. C. truncatus & -0.3611 & 0.6209 & 0.3382 & 0.5609 \\
Day & Days 4-9 vs. 1-3 & 0.4910 & 0.5583 & 0.7734 & 0.3792 \\
\hline
\end{tabular}

${ }^{\text {a }}$ Model: logit (odds of success) $=$ constant + species + day. All explanatory variables are factors where estimates are compared with the first level; $\mathrm{SE}=$ standard error. summer and fall in the eastern and central United States. Fall wounding studies in Minnesota found that contaminated nitidulid beetles visiting fresh wounds were very infrequent between early July and midOctober (16). Timing of mat production or beetle populations may be different in Missouri.

Results of this study conflict with the previous assertion that nitidulid beetles are not important in transmission of $C$. $f a$ gacearum in Missouri (4). We hypothesize that Colopterus niger, $C$. truncatus, and $C$. semitectus are principal nitidulid beetle species responsible for pathogen transmission in east-central Missouri based on their abundances in fresh wounds during spring months and their frequencies of contamination with the pathogen. In contrast, $C$. truncatus and Carpophilus sayi are considered the principal sap beetle vectors in Minnesota, based on abundance of contaminated insects in oak-wilt-affected stands and their frequent presence on oak wilt mats during spring months $(2,7,17)$. Interestingly, $C$. truncatus and $C$. semitectus also were ranked high as principal insect vector species in Iowa based on their abundance in oak wilt mats and in $\leq 2$ week-old wounds (22). The picture of nitidulid beetle transmission of Ceratocystis fagacearum in Texas is incomplete at this time. In addition to Colopterus truncatus, three species (C. maculatus, Cryptarcha concinna, and Lobiopa undulata) were found dispersing with Ceratocystis fagacearum in oak wilt centers in Texas (1). The role of these three species in transmission in Texas is unclear.

Overall, we hypothesize that Colopterus truncatus is a common nitidulid beetle species vector of Ceratocystis fagacearum in at least three parts of the oak wilt disease range (i.e., the Upper Midwest, the Mid-Atlantic States, and Texas). Although assays for pathogen presence were not conducted, Colopterus truncatus also has been reported on oak wilt mats or in fresh wounds in Illinois, West Virginia, Wisconsin, and Pennsylvania $(9,19,30,31)$.

This study did not investigate the involvement of oak bark beetles in Ceratocystis fagacearum transmission in Missouri and it is possible that oak bark beetles also are contributing to pathogen spread. The importance of oak bark beetles in Missouri was established by Berry and Bretz, who found that $27 \%$ of Pseudopityophthorus minutissimus carried the oak wilt fungus upon emergence from oakwilt-killed trees in Missouri (4). Also, in a 1972 study in Missouri, about 50\% of the oak-wilt-killed trees examined were colonized by oak bark beetles (27). However, in a recent study, very few oak bark beetles were captured dispersing through the crowns of oak wilt trees in Central Missouri (M. C. Hayslett, unpublished). In that study, $180 \quad P$. minutissimus individuals were collected from one of four trees be- 
tween mid-April and mid-June in 2005 and $30 \mathrm{P}$. minutissimus individuals were collected from eight trees over the same time period in 2006. None of the beetles assayed carried the oak wilt fungus. These conflicting data suggest that more information is needed about oak bark beetle transmission of the oak wilt fungus.

Results of this study support adherence to disease control guidelines known to reduce probability or incidence of overland transmission of the oak wilt pathogen in other states (6). Now that nitidulid beetles have been demonstrated to carry viable propagules of the fungus to wounds on healthy oak trees in Missouri, the removal of recently wilted red oak species prior to oak wilt mat formation is also prudent. Second, plans for cutting of oak trees in forest lands and pruning in more urban or suburban settings during spring months, particularly April and May, should be scrutinized carefully if oak wilt is known to occur within the county or even closer to the work area. Based on our study, the highest risk months for overland spread in Missouri appear to be April and May. Further studies should be conducted to test this conjecture. These include a temporally and spatially expanded wounding study, monitoring of dispersing sap beetle species in active oak wilt areas using insect pheromone baited flight traps (2), and documentation of sap beetle species inhabiting oak wilt mats during the spring and fall months.

\section{ACKNOWLEDGMENTS}

We thank the United States Department of Agriculture Forest Service for funding through a cost reimbursable agreement and the TREE Fund for the John Z. Duling grant that provided additional support for this project; the Prairie Garden Trust for allowing us to work on their land; D. Brandt at the Missouri Department of Conservation for field assistance; and A. McKnite and S. French for technical assistance.

\section{LITERATURE CITED}

1. Appel, D. N., Kurdyla, T., and Lewis, R., Jr. 1990. Nitidulids as vectors of the oak wilt fun- gus and other Ceratocystis spp. in Texas. Eur. J. For. Pathol. 20:412-417.

2. Ambourn, A. K., Juzwik, J., and Moon, R. D. 2005. Seasonal dispersal of the oak wilt fungus by Colopterus truncatus and Carpophilus sayi in Minnesota. Plant Dis. 89:1067-1076.

3. Barnett, H. L. 1953. Isolation and identification of the oak wilt fungus. W. Va. Univ. Agric. Exp. Stn. Bull. 359T.

4. Berry, F. H., and Bretz, T. W. 1966. Small oak bark beetle a potential vector of oak wilt. Plant Dis. Rep. 50:45-49.

5. Buchanan, W. D. 1958. The small oak bark beetle transmits the oak wilt disease. J. For. 56:414-415.

6. Carlson, J. C., and Martin, A. J. 2005. Oak wilt management-What are the options? Univ. Wisc. Ext. Publ. G3590, Madison.

7. Cease, K. R., and Juzwik, J. 2001. Predominant nitidulid species (Coleoptera: Nitidulidae) associated with spring oak wilt mats in Minnesota. Can. J. For. Res. 31:635-643.

8. Cook, R. D., and Weisberg, S. 1999. Pages 475-489 and 545-570 in: Applied Regression Including Computing and Graphics. John Wiley and Sons Inc., New York.

9. Curl, E. A. 1955. Natural availability of oak wilt inocula. Ill. Nat. Hist. Surv. Bull. 26:277323.

10. Dorsey, C. K., and Leach, L. G. 1956. The bionomics of certain insects associated with oak wilt with particular reference to the Nitidulidae. J. Econ. Entomol. 49:219-230.

11. Gibbs, R. D., and French, D. W. 1980. The transmission of oak wilt. U. S. Dep. Agric. For. Serv. Res. Pap. NC-185.

12. Grant, V. 1950. The pollination of Calycanthus occidentalis. Am. J. Bot. 37:294-297.

13. Hayslett, M., Juzwik, J., Camilli, K., and Appel, D. 2005. Frequencies of Ceratocystis fagacearum contaminated nitidulid beetle species in wounds on live and red oaks in Texas. (Abstr.) Phytopathology 95:S41.

14. Jones, T. W., and Partridge, A. D. 1961. The importance of root grafts in oak wilt spread in Missouri. Plant Dis. Rep. 45:506-507.

15. Juzwik, J., Cook, S., Haugen, L., and Elwell, J. 2004. Oak wilt: People and trees, a community approach to management. U. S. Dep. Agric. For. Serv. Gen. Tech. Rep. NC-240.

16. Juzwik, J., Hayslett, M., Kyhl, J. F., and Ambourn, A. K. 2006. Low risk of oak wilt pathogen spread by sap beetles during summer and fall. (Abstr.) Phytopathology 96:S57.

17. Juzwik, J., Skalbeck, T. C., and Neuman, M. F. 2004. Sap beetle species (Coleoptera: Nitidulidae) visiting fresh wounds on healthy oaks dur- ing spring in Minnesota. For. Sci. 50:757-764.

18. Kuntz, J. E., and Drake, C. R. 1957. Tree wounds and long distance spread of oak wilt. Phytopathology. 47:22.

19. McMullen L. H., Shenefelt, R. D., and Kuntz, J. E. 1960. A study of insect transmission of oak wilt in Wisconsin. Wisc. Acad. Sci. Arts Lett. 49:73-84.

20. Moser, W. K, Brand, G. J., Treiman, T., Moltzan, B., and Lawrence, R. 2004. Missouri's forest resources in 2002. U. S. Dep. Agric. For Serv. Resour. Bull. NC-233.

21. Moser, W. K, Hansen, M. H., Treiman, T., Piva, R., Woodall, C., Perry, C. H., Leatherberry, E. C., Olson, C., and Brand, G. J. Missouri's forests: Status and changes a report on the state's forest resources 1999-2003. U. S Dep. Agric. For. Serv. Resour. Bull. In press.

22. Norris, D. M. 1956. Association of insects with the oak tree and Endoconidiophora fagacearum Bretz. Ph. D. thesis, Iowa State University, Ames.

23. O'Brien, J. G., Mielke, M. E., Starkey, D., and Juzwik, J. 2000. How to identify, prevent and control oak wilt. U. S. Dep. Agric. For. Serv. NA-PR-03-00.

24. Parsons, C. T. 1943. A revision of the nearctic Nitidulidae (Coleoptera). Bull. Mus. Comp. Zool. 92:120-278.

25. Piva, R. J., and Treiman, T. B. 2003. Missouri timber industry-an assessment of timber product output and use, 2000. U. S. Dep. Agric. For. Serv. Resour. Bull. NC-223.

26. Rexrode, C. O., and Jones, T. W. 1970. Oak bark beetles, important vectors of oak wilt. J. For. 68:294-297.

27. Rexrode, C. O., and Jones, T. W. 1972. Oak bark beetle attacks on oak wilt trees in Missouri. Environ. Entomol.1:57-58.

28. Rickson, F. R. 1979. Ultrastructural development of beetle food tissue of Calycanthus flowers. Am. J. Bot. 66:80-86.

29. Smith, W. B., Miles, P. D., Vissage, J. S., and Pugh, S. A. 2004. Forest resources of the United States, 2002. U. S. Dep. Agric. For Serv. Gen. Tech. Rep. NC-241.

30. Stambaugh, W. J., and Fergus, C. L. 1956 Longevity of spores of the oak wilt fungus on overwintering nitidulid beetles. Plant. Dis. Rep. 40:919-922.

31. True, R. P., Barnett, H. L., Dorsey, C. K., and Leach, J. G. 1960. Oak wilt in West Virginia. W. Va. Agric. Exp. Stn. Bull. 448T.

32. Zuckerman, B. M. 1954. Relation of type and age of wound to infection by Endoconidiophora fagacearum Bretz. Plant Dis. Rep. 38:290-292. 